\title{
Neospora caninum: Seroprevalence in beef cattle in the mountainous region of Santa Catarina, Brazil
}

\section{Neospora caninum: Soroprevalência em bovinos de corte na região serrana de Santa Catarina, Brasil}

\author{
Mayckon Antonio Cardoso Padilha ${ }^{1}$; Gefferson Wasen²; Antonio Pereira de Souza ${ }^{3}$; \\ Viviane Milczewski ${ }^{4}$; Thaís Vaz Brito da Luz ; Amélia Aparecida Sartor ${ }^{6}$; \\ Juliana Antunes Farias ${ }^{7}$; Anderson Barbosa de Moura ${ }^{8 *}$
}

\begin{abstract}
The distribution of Neospora caninum, an important agent of reproductive disorders in cattle, has been frequently reported in dairy cattle in Brazil and worldwide. Records of infection are less frequent in beef cattle. To determine the seroprevalence of bovine neosporosis, 507 beef cattle blood samples were collected from January 2013 to September 2015, from 16 municipalities of the Associação dos Municípios da Região Serrana (AMURES). Samples were tested for the presence of IgG antibodies $(\geq 1: 100)$ against $N$. caninum by indirect immunofluorescence antibody test (IFAT). Information about sex, age, and origin of the bovines were obtained from the Brazilian Bovine and Bubaline Identification and Certification System (SISBOV), and were tabulated for statistical analysis (Chi-square and Fisher Exact test, $\mathrm{P} \leq 0.05)$. Of the 507 serum samples analyzed, 70 (13.81\%) contained antibodies against $N$. caninum with titers of 1:100 (16), 1:200 (22), 1:400 (17), 1:800 (nine), 1:1600 (four) and 1:3200 (two). Positive specimens were collected from 13 of the 16 municipalities and across all age groups. Of the positive samples, there were no statistical differences between males and females (32.86\% vs. $67.14 \%$, $\mathrm{P}=0.1072)$, age groups $(\mathrm{P}=0.4116)$, or municipalities $(\mathrm{P}=0.6838)$. While not statistically significant $(\mathrm{P}>0.05)$, higher seroprevalence was observed among older females. Although seroprevalence was relatively low, results indicate that infection by $N$. caninum in beef cattle is widespread in the studied region.
\end{abstract}

Key words: Neospora caninum. Prevalence. Beef cattle. Santa Catarina.

1 Discente do Curso de Mestrado no Programa de Pós-Graduação em Ciência Animal, Centro de Ciências Agroveterinárias, CAV, Universidade do Estado de Santa Catarina, UDESC, Lages, SC, Brasil. E-mail: mayck1000@hotmail.com

2 Discente do Curso de Graduação em Medicina Veterinária e Bolsista de IC do Centro de Ciências Agroveterinárias, CAV, UDESC, Lages, SC, Brasil. E-mail: geff_wasen@hotmail.com

3 Prof. Visitante Sênior, Instituto Federal Catarinense, IFC, Campus de Araquari, Bolsista PVNS/CAPES e Prof. Voluntário do Programa de Pós-Graduação em Ciência Animal do CAV/UDESC, Lages, SC, Brasil. E-mail: antonio.souza@ifc-araquari.edu. br; antonio.souza@udesc.br

4 Prof., Curso de Medicina Veterinária do Instituto Federal Catarinense, IFC, Campus Araquari, Araquari, SC, Brasil. E-mail: viviane.milczewski@ifc-araquari.edu.br

5 Médica Veterinária do Frigorífico São João, FRISAJO, São João do Itaperiú, SC, Brasil. E-mail: thaisvazbrito@gmail.com

${ }^{6}$ Docente do Curso de Medicina Veterinária, Centro de Ciências Agroveterinárias, CAV, UDESC, Lages, SC, Brasil. E-mail: amelia.sartor@udesc.br

7 Discente do Curso de Doutorado no Programa de Pós-Graduação em Ciência Animal, Centro de Ciências Agroveterinárias, CAV, UDESC, Lages, SC, Brasil. E-mail: juliana0807@hotmail.com

8 Prof., Programa de Pós-Graduação em Ciência Animal, Centro de Ciências Agroveterinárias, CAV, UDESC, Lages, SC, Brasil. E-mail: anderson.moura@udesc.br

* Author for correspondence 


\title{
Resumo
}

\begin{abstract}
A distribuição de Neospora caninum, importante agente de desordens reprodutivas em bovinos, tem sido frequentemente reportada em gado leiteiro no Brasil e no mundo, sendo menos frequentes os registros em bovinos de corte. Com o objetivo de determinar a soroprevalência da neosporose bovina, de Janeiro de 2013 a Setembro de 2015 foram colhidas 507 amostras de sangue de bovinos de corte, provenientes de 16 municípios integrantes da Associação dos Municípios da Região Serrana (AMURES), para a realização da Reação da Imunofluorescência Indireta (RIFI) para a detecção de anticorpos $(\geq 1: 100)$ IgG contra $N$. caninum. Informações de sexo, idade e procedência dos animais foram obtidas por meio dos registros no SISBOV (Serviço Brasileiro de Rastreabilidade da Cadeia Produtiva de Bovinos e Bubalinos), e foram tabulados para a análise estatística (Testes exato de Fisher e do Qui-Quadrado, $\mathrm{P} \leq 0,05)$. Das 507 amostras analisadas, 70 foram positivas, em 13 dos 16 municípios e em todas as faixas etárias foram identificados animais positivos. Os resultados indicam uma prevalência de 13,81\% (70/507) com títulos de anticorpos de 1:100 (16), 1:200 (22), 1:400 (17), 1:800 (nove), 1:1600 (quatro) e 1:3200 (dois). Das amostras positivas 32,86\% (23/70) foram de machos e 67,14\% (47/70) de fêmeas, sem diferenças estatísticas $(\mathrm{P}=0,1072)$, assim como idade $(\mathrm{P}=0,4116)$ e município $(\mathrm{P}=0,6838)$. Embora sem correlação estatística $(\mathrm{P}>0,05)$, maior soroprevalência foi observada entre as fêmeas mais velhas. Apesar de a soroprevalência observada no presente estudo ter sido relativamente baixa, os resultados indicam que a infecção por $N$. caninum em bovinos de corte está amplamente distribuída na região estudada.
\end{abstract}

Palavras-chave: Neospora caninum. Prevalência. Bovinos de corte. Santa Catarina.

\section{Introduction}

In various regions of the world Neospora caninum is considered one of the main causes of abortions in dairy cattle (DUBEY, 1999; MARQUES et al., 2011) and can infect several animal species including domestic and wild canids, horses, goats and deers (DUBEY, 2003; VARASCHIN et al., 2012). In cattle, $N$. caninum has an efficient vertical transmission capacity (DUBEY, 2003), infecting $90 \%$ of animals in a herd (DUBEY et al., 2006) via transplacental, either exogenous or endogenous route.

It can also be transmitted horizontally to cattle by ingestion of sporulated oocysts excreted by infected dogs (DUBEY; SCHARES, 2011). Currently dogs (Canis lupus familiaris), coyotes (Canis latrans), dingoes (Canis lupus dingo) and gray wolves (Canis lupus), are the only species recognized as definitive hosts (DUBEY et al., 2011; GONDIM et al., 2004; KING et al., 2010; McALLISTER et al., 1998). It has been reported that the presence of coyotes may increase infection rates up to 2.4 times (CONZUELO SIERRA et al., 2011) and dogs up to 3.21 times (PORTOCARRERO et al., 2015), thus increasing the risk of infection in herd animals.
The primary sign observed in cows infected with $N$. caninum is abortion, usually between the fifth and seventh month of gestation (CAMPERO et al., 2003). Repeated estrus, successive miscarriages, and temporary anestrus are related to infection by N. caninum (BRUHN et al., 2013).

Reichel et al. (2013) estimated global losses caused by $N$. caninum to be more than $\$ 1$ billion, with two-thirds of losses occurring in the dairy industry and one-third in the beef industry. In Brazil, N. caninum is widespread (CAMILLO et al., 2010), but little is known about its costs to the economy. Although rates of infection have been previously documented in this territory, it is believed that these exceed other abortive diseases such as brucellosis and leptospirosis (SARTOR et al., 2003). Reichel et al. (2013) estimated that in South America the annual cost associated with neosporosis can reach US \$ 239.7 million per year, US \$ 51.3 and US \$ 101.0 million in the Brazil's dairy and meat industries, respectively.

Serological analysis of $N$. caninum associated with the occurrence of reproductive problems is an important tool to define the possible diagnosis and 
to control outbreaks of the parasite in bovine herds (PAZ et al., 2007). The seroepidemiological results in Brazil have been variable. This is perhaps due to the number of samples collected, characteristics and size of herds, and lack of reproductive history of analyzed samples (CAMILLO et al., 2010).

There are several recent studies of $N$. caninum, both globally and in Brazil, however, little is known about the occurrence and prevalence of infection in beef cattle in the state of Santa Catarina, especially in the mountainous region, which is an important area for cattle reproduction. The objective of this study was to determine seroprevalence of $N$. caninum infection in beef cattle in the mountainous region of Santa Catarina, southern Brazil.

\section{Material and Methods}

From January 2013 to September 2015, 507 beef cattle blood samples were collected from 16 municipalities of the Associação dos Municípios da Região Serrana (AMURES). This mountainous region of Santa Catarina has an average altitude of 740 meters above sea level, with a minimum of 716 meters recorded in Abdon Batista and a maximum of 1353 meters in São Joaquin. The climate is a humid mesothermal type, with an average temperature of $16^{\circ} \mathrm{C}$. There are also areas that experience subtropical and temperate climates with cold winters and temperatures reaching below $0^{\circ} \mathrm{C}$.

The bovine population in the mountainous region of Santa Catarina is 557,826 (IBGE, 2012), representing approximately $18 \%$ of beef production in the state of Santa Catarina. The number of samples required to estimate the prevalence of $N$. caninum was calculated using an expected prevalence of $15 \%, 3.0 \%$ error and 95\% confidence level (OPS, 1979).

The samples were taken at random from animals on properties in AMURES region and from four slaughterhouses, located in the municipalities of Lages (S.I.E 004), Otacílio Costa (S.I.E 620), São
João do Itaperiú (S.I.E 041) and São Joaquim (S.I.E 470). Sera were stored $\left(-20^{\circ} \mathrm{C}\right)$ until processed for the detection of IgG antibodies against $N$. caninum by indirect immunofluorescence antibody test (IFAT).

Of the 507 samples, $215(42.41 \%)$ were males and 292 (57.59\%) females. The animals were also divided by age, establishing four groups: $0 \leq \mathrm{a} \leq$ 2 years $(n=68,13.41 \%), 2<a \leq 4$ years $(n=195$, $38.46 \%), 4<\mathrm{a} \leq 8$ years $(\mathrm{n}=139,27.42 \%)$ and $>8$ years $(n=105,20.71 \%)$.

To perform the IFAT, according to Dubey et al. (1988), NC1 tachyzoites of N. caninum strain were used as the antigen. Samples that showed a reaction at the dilution 1:100 were considered positive (MINERVINO et al., 2008) and were sequentially diluted in multiples of two, to reach the final reactive maximum dilution for titration. For comparison, positive and negative sera were used as controls.

Information about sex, age, and origin of the animals were obtained through the records in the Brazilian Bovine and Bubaline Identification and Certification System (SISBOV), and were tabulated for statistical analysis (Chi-square and Fisher Exact test, $\mathrm{P} \leq 0,05)$ to correlate the results of the serological analysis with the population data.

This study was approved by the Animal Experimentation Ethics Committee (CETEA), of the Agroveterinárias Science Center (CAV) of the State University of Santa Catarina (UDESC) under protocol 01.29.14, of June 3, 2014.

\section{Results and Discussion}

Of the 507 serum samples analyzed, 70 had antibodies against $N$. caninum, resulting in a prevalence of $13.81 \%$ in the mountainous region of Santa Catarina. These results are similar to those recorded in a study by Moura et al. (2012a), which found a prevalence of $13.2 \%$ in beef cattle in the micro region of Guarapuava, state of Paraná, Brazil. 
Positive animals were identified in 13 of the 16 municipalities and across all age groups. Twentythree $(32.86 \%)$ of the positive samples were males and $47(67.14 \%)$ female. The antibody titers and number of positive animals were 1: 100 (16), 1: 200 (22), 1: 400 (17), 1: 800 (nine), 1: 1600 (four) and 1: 3200 (two).

Previous studies have shown the circulation of the agent in different species in the mountainous region of Santa Catarina with occurrence of $\mathrm{IgG}$ antibodies against $N$. caninum in $13.0 \%$ of dogs in urban areas of Lages (MOURA et al., 2011), $21.2 \%$ of dogs in rural areas of Lages (MOURA et al., 2012b), 2.6\% of horses (MOURA et al., 2013), $4.58 \%$ of goats (TOPAZIO et al., 2014) and 5.83\% and $7.0 \%$ of sheep (DALLA ROSA et al., 2011; MOURA et al., 2014).

In a comparable study conducted in the mountainous region of Santa Catarina, Moura et al. (2012b) reported seropositivity (IFAT, $\geq 1$ : $200)$ in dairy cattle $(23.1 \%)$ to be higher than that observed in beef cattle from this study (13.81\%). In addition to the different cutoff points used (1:200 vs. $1: 100)$, this discrepancy of results, in the same animal species and in the same region, may be linked to the different management conditions employed in each production system (beef or dairy) (DUBEY et al., 2007), or to differences in the mechanism of the humoral response of dairy and beef (SANTOLARIA et al., 2011). For example, the extensive management beef cattle are subjected to in this region does not favor their contact with the dogs. The opposite occurs with dairy cattle, which are herded at least once a day to the milking facilities near the headquarters, where normally focus the dogs of the properties. In addition, beef cattle in the region studied rarely receive supplementation, which can also be related to lower prevalence in these animals. In comparison, dairy cattle receive concentrate, which has been identified as a risk factor for infection by $N$. caninum in bovine (ARREOLACAMBEROS et al., 2012). In contrast, Hasegawa et al. (2004) reported that winter supplementation (corn, silage, sugarcane and Napier) did not affect the infection rate for $N$. caninum in beef cattle in the region of Avaré (SP).

Also, with respect to the type of animal (beef or dairy), Eiras et al. (2011), observed a greater number of dairy herds containing at least one positive animal, when compared to beef herds in Spain. However, individually, beef cattle, presented higher seropositivity. In comparison, Vanleeuwen et al. (2006) observed a higher seroprevalence of neosporosis in cattle beef herds than in dairy herds in Canada, but no difference was observed in the case of individual animals. These authors concluded that these differences may be partly due to employee tests to laboratories where they performed the tests or both, which can make inappropriate statistical comparisons in certain situations. These findings show variable results and indicate that only the type of activity does not to influences decisively the prevalence of infection in cattle.

This study found no significant differences in seropositivity between the municipalities ( $\mathrm{P}>$ 0.05). Geographic differences in the distribution of animals infected by $N$. caninum have been reported in other studies and may be related, among other factors, to the relative abundance of the definitive host (canidae) as well as the management systems utilized (NASIR et al., 2012).

There were no statistically significant differences between the age groups with respect to seropositivity $(\mathrm{P}>0.05)$. Such results do not identify whether horizontal or vertical transmission is the primary route of infection and maintenance of $N$. caninum in beef cattle. Although congenital transmission is considered the most important form of infection for $N$. caninum in cattle, the results of this study suggests that both vertical and horizontal transmission seem to have equal importance in the epidemiology of infection in beef cattle, similar to a study by Moré et al. (2010) in Argentina.

Several experiments also found no correlation between seropositivity and the variables (FERNÁNDEZ; GARCÍA, 2014; GHAREKHANI, 
2014; SILVA et al., 2015). Portocarrero et al. (2015) found no correlation between seropositivity and the age or origin $(\mathrm{P}>0.05)$ of animals in Peru. Marques et al. (2011) tested 159 samples from the northern state of Paraná and reported that the prevalence of $N$. caninum in cows did not increase proportionally with the age of the infected animal $(\mathrm{P}=0.43)$.

Despite $67.14 \%$ of seropositive animals to $N$. caninum being females, no association was observed between positive serology and sex $(\mathrm{P}>0.05)$. This gender difference can be attributed to sampling where of the total $(n=507)$ samples, $292(57.6 \%)$ were females (Table 1). These values are consistent with those reported by Gharekhani et al. (2014), in which they did not observe statistically significant $(\mathrm{P}>0.5)$ differences between seropositivity and age, race or sex of animals tested in Iran.

Table 1. Serology (IFAT, $\geq 1: 100$ ) to Neospora caninum in beef cattle in the mountainous region of Santa Catarina, Brazil.

\begin{tabular}{|c|c|c|c|c|c|c|c|}
\hline \multirow{2}{*}{ Variables } & \multirow{2}{*}{ Categories } & \multicolumn{2}{|c|}{ Animals } & \multicolumn{2}{|c|}{ Positive $^{1}$} & \multicolumn{2}{|c|}{ Positive $^{2}$} \\
\hline & & $n$ & $\%$ & $n$ & $\%$ & $\mathbf{n}$ & $\%$ \\
\hline \multirow{16}{*}{ 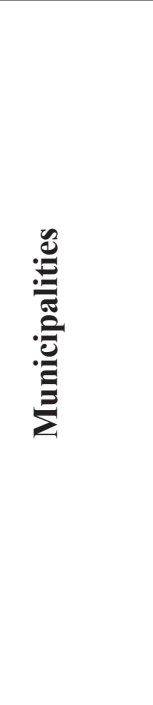 } & Anita Garibaldi & 14 & 2.76 & 0 & 0 & 0 & 0 \\
\hline & Bocaína do Sul & 12 & 2.37 & 3 & 25 & 3 & 4.29 \\
\hline & Bom Jardim da Serra & 25 & 4.93 & 4 & 16 & 4 & 5.71 \\
\hline & Bom Retiro & 35 & 6.9 & 5 & 14.29 & 5 & 7.14 \\
\hline & Campo Belo do Sul & 14 & 2.76 & 2 & 14.29 & 2 & 2.86 \\
\hline & Capão Alto & 38 & 7.5 & 4 & 10.53 & 4 & 5.71 \\
\hline & Correia Pinto & 36 & 7.1 & 8 & 22.22 & 8 & 11.43 \\
\hline & Lages & 107 & 21.1 & 16 & 14.95 & 16 & 22.86 \\
\hline & Otacílio Costa & 18 & 3.55 & 3 & 16.67 & 3 & 4.29 \\
\hline & Painel & 38 & 7.5 & 3 & 7.90 & 3 & 4.29 \\
\hline & Palmeira & 15 & 2.96 & 1 & 6.67 & 1 & 1.43 \\
\hline & Ponte Alta & 5 & 0.99 & 0 & 0 & 0 & 0 \\
\hline & Rio Rufino & 7 & 1.38 & 0 & 0 & 0 & 0 \\
\hline & São Joaquim & 85 & 16.8 & 11 & 12.94 & 11 & 15.71 \\
\hline & São José do Cerrito & 45 & 8.88 & 9 & 20 & 9 & 12.86 \\
\hline & Urupema & 13 & 2.56 & 1 & 7.69 & 1 & 1.43 \\
\hline \multirow{2}{*}{ Sex } & Male & 215 & 42.4 & 23 & 10.7 & 23 & 32.86 \\
\hline & Female & 292 & 57.6 & 47 & 16.1 & 47 & 67.14 \\
\hline \multirow{4}{*}{$\begin{array}{c}\text { Age } \\
\text { (years) }\end{array}$} & $0 \leq \mathrm{a} \leq 2$ & 68 & 13.4 & 6 & 8.82 & 6 & 8.57 \\
\hline & $2<\mathrm{a} \leq 4$ & 195 & 38.5 & 26 & 13.33 & 26 & 37.14 \\
\hline & $4<\mathrm{a} \leq 8$ & 139 & 27.4 & 24 & 17.27 & 24 & 34.29 \\
\hline & $>8$ & 105 & 20.7 & 14 & 13.33 & 14 & 20 \\
\hline Total & - & 507 & 100 & 70 & 13.81 & 70 & 100 \\
\hline
\end{tabular}

Although no statistical difference occurred between age and sex with seropositivity separately, these two variables (age and sex) appear to act in concert. It can be noted that females had higher prevalence rates in all age groups compared with males, as well as certain constancy of results in all age groups analyzed (Table 2). This may be due to the majority of tested male animals being at a young age, while older animals were more heavily sampled for females. Thus, taking into account the increased risk of exposure to the parasite with increasing age (BARTELS et al., 2006) and the 
differing sample size in age groups, it was expected that older females would contain a greater number of positive animals than young males.

There are few studies about seroprevalence of antibodies against $N$. caninum, specifically in beef cattle. Some data in Brazil reports prevalences of $12.6 \%$ for cows and $16.7 \%$ for fetuses, in the states of Pernambuco and Alagoas (AMARAL et al, 2012.); $14.6 \%$ in pregnant and $15.8 \%$ in non-pregnant females, in the state of Paraná (MARQUES et al., 2011) and 19.9\% in the region of Presidente Prudente in São Paulo (VIANNA et al., 2008). In contrast, Nascimento et al. (2014) reported seroprevalence of $30.3 \%$ in pregnant zebu cows in the state of Paraná, with a rate of vertical transmission of $29 \%$ and a 26.25 fold increased risk of vertical transmission in a seropositive compared to a seronegative cow.

Although reproductive rates were not evaluated in this study, infection with $N$. caninum in beef cattle may represent losses. In Brazil, Andreotti et al. (2010) observed higher seroprevalence of $N$. caninum in animals with gestational problems than in cows that had conceived, and reduced extraction rates in seropositive heifers compared to seronegative animals.

Table 2. Seroprevalence of Neospora caninum associated with age and sex of beef cattle from the mountainous region of Santa Catarina, Brazil.

\begin{tabular}{|c|c|c|c|c|c|}
\hline \multirow{2}{*}{\multicolumn{2}{|c|}{ Age (years) }} & \multicolumn{4}{|c|}{ Sex } \\
\hline & & \multicolumn{2}{|c|}{ Male } & \multicolumn{2}{|c|}{ Female } \\
\hline \multirow{3}{*}{$0 \leq \mathrm{to} \leq 2$} & Positive & 3 & 6.12 & 3 & 15.79 \\
\hline & Negative & 46 & 93.88 & 16 & 84.21 \\
\hline & & 49 & 100 & 19 & 100 \\
\hline \multirow{3}{*}{$2<t 0 \leq 4$} & Positive & 17 & 12.5 & 9 & 15.25 \\
\hline & Negative & 119 & 87.5 & 50 & 84.75 \\
\hline & & 136 & 100 & 59 & 100 \\
\hline \multirow{3}{*}{$4<$ to $\leq 8$} & Positive & 3 & 10.71 & 21 & 18.92 \\
\hline & Negative & 25 & 89.29 & 90 & 81.08 \\
\hline & & 28 & 100 & 111 & 100 \\
\hline \multirow{3}{*}{$>8$} & Positive & 0 & 0 & 14 & 13.59 \\
\hline & Negative & 2 & 100 & 89 & 86.41 \\
\hline & & 2 & 100 & 103 & 100 \\
\hline \multirow{2}{*}{ Total } & Positive & 23 & 10.7 & 47 & 16.1 \\
\hline & Negative & 192 & 89.3 & 245 & 83.9 \\
\hline \multicolumn{2}{|c|}{ Total } & 215 & 100 & 292 & 100 \\
\hline
\end{tabular}

\section{Conclusion}

The results of the present study demonstrated wide distribution, with a relatively low seroprevalence of $N$. caninum in beef cattle herds in the mountainous region of Santa Catarina. The prevalence of antibodies against $N$. caninum was $13.81 \%$ and, although with no statistical correlation ( $\mathrm{P}>0.05$ ), a higher incidence of seropositive animals was observed among older females. 


\section{Achnowledgments}

Funding was provided by the Fundação de Amparo à Pesquisa e Inovação do Estado de Santa Catarina (FAPESC) through the Public Calls FAPESC No 06/2013 and 04/2014 - Grant Terms $3541 / 2013$ and 293/2015 - Infrastructure Support for Research Groups of the Universidade do Estado de Santa Catarina (UDESC); Companhia Integrada de Desenvolvimento Agrícola de Santa Catarina (CIDASC) and the Fundo de Apoio à Manutenção e ao Desenvolvimento da Educação Superior (FUMDES).

\section{References}

AMARAL, R. L. G.; SILVA, L. B. G.; PINHEIRO JÚNIOR, J. W.; SOUZA NETO, O. L.; LEAL, C. A. S.; PORTO, W. J. N.; BARBOSA, J. M. P.; MOTA, R. A. Neospora caninum em bovinos em matadouros de Pernambuco e Alagoas. Pesquisa Veterinária Brasileira, Seropédica, v. 32, n. 10, p. 963-966, 2012.

ANDREOTTI, R.; BARROS, J. C.; PEREIRA, A. R.; OSHIRO, L. M.; CUNHA, R. C.; FIGUEIREDO NETO, L. F. Association between seropositivity for Neospora caninum and reproductive performance of beef heifers in the Pantanal of Mato Grosso do Sul, Brazil. Revista Brasileira de Parasitologia Veterinária, Jaboticabal, v. 19, n. 2, p. 119-123, 2010.

ARREOLA-CAMBEROS, S.; GARCIA-MARQUEZ, L. J.; MACEDO-BARRAGAN, R.; MORALESSALINAS, E.; FIGUEROA-CHAVEZ, D. Risk Factors and seroprevalence against Neospora caninum in dualpurpose and beef cattle in Colima, Mexico. Journal of Animal and Veterinary Advances, Faisalabad, v. 11, n. 14, p. 2440-2444, 2012.

BARTELS, C. J. M.; ARNAIZ-SECO, J. I.; RUIZSANTA-QUITERA, A.; BJÖRKMAN, C.; FRÖSSLING, J.; VON BLUMRÖDER, D.; CONRATHS, F. J.; SCHARES, G.; VAN MAANEN, C.; WOUDA, W.; ORTEGA-MORA, L. M. Supranational comparison of Neospora caninum seroprevalences in cattle in Germany, The Netherlands, Spain and Sweden. Veterinary Parasitology, Amsterdam, v. 137, n. 1, p. 17-27, 2006.

BRUHN, F. R.P.; DAHER, D. O.; LOPES, E.;BARBIERI, J. M.; ROCHA, C. M. B. M. da; GUIMARÃES, A. M. Factors associated with seroprevalence of Neospora caninum in dairy cattle in southeastern Brazil. Tropical Animal Health and Production, New York, v. 45, n. 5, p. 1093-1098, 2013.

CAMILLO, G.; CADORE, G.; CEZAR, A. S.; TOSCAN, G.; BRAUNIG, P.; SANGIONI, L. A.; VOGEL, F. S. Anticorpos anti-Neospora caninum em bovinos de leite do sudoeste do estado do Paraná. Arquivo Brasileiro de Medicina Veterinária e Zootecnia, Belo Horizonte, v. 62, n. 6, p. 1511-1513, 2010.

CAMPERO, C. M.; MOORE, D. P.; ODEÓN, A. C.; CIPOLLA, A. L.; ODRIOZOLA, E. A etiology of bovine abortion in Argentina. Veterinary Research Communications, Dordrecht, v. 27, n. 5, p. 359-369, 2003.

CONZUELO SIERRA, R.; MEDINA-ESPARZA, L.; RAMOS PARRA, M.; GARCÍA-VÁZQUEZ, Z.; CRUZ-VÁZQUEZ, C. Factores de riesgo asociados a la seroprevalencia de anticuerpos a Neospora caninum en ganado lechero de Aguascalientes, México. Revista Mexicana de Ciencias Pecuarias, Mérida, v. 2, n. 1, p. 15-24, 2011.

DALLA ROSA, L.; MOURA, A. B.; GÜTHS, M. F.; BELlATO, V.; SARTOR, A. A.; SOUZA, A. P. Prevalência e fatores de risco para infecção por Neospora caninum em ovinos no município de Lages, Santa Catarina, Brasil. Revista de Ciências Agroveterinárias. Lages, v. 10, n. 2, p. 127-137, 2011.

DUBEY, J. P. Recent advances in Neospora and neosporosis. Veterinary Parasitology, Amsterdam, v. 84, n. 3, p. 349-367, 1999.

Review of Neospora caninum and neosporosis in animals. The Korean Journal of Parasitology, Seoul, v. 41, n. 1, p. 1-16, 2003.

DUBEY, J. P.; BUXTON, D.; WOUDA, W. Pathogenesis of bovine neosporosis. Journal of Comparative Pathology, Amsterdam, v. 134, n. 4, p. 267-289, 2006.

DUBEY, J. P.; HATTEL, A. L.; LINDSAY, D. S.; TOPPER, M. J. Neonatal Neospora caninum infection in dogs: isolation of the causative agent and experimental transmission. Journal of the American Veterinary Medical Association, Chicago, v. 193, n. 10, p. 1259-1263, 1988.

DUBEY, J. P.; JENKINS, M. C.; RAJENDRAN, C.; MISKA, K.; FERREIRA, L. R.; MARTINS, J.; KWOK, O. C. H.; CHOUDHARY, S. Gray wolf (Canis lupus) is a natural definitive host for Neospora caninum. Veterinary Parasitology, Amsterdam, v. 181, n. 2, p. 382-387, 2011.

DUBEY, J. P.; SCHARES, G. Neosporosis in animals the last five years. Veterinary Parasitology, Amsterdam, v. 180 , n. 1 , p. $90-108,2011$. 
DUBEY, J. P.; SCHARES, G.; ORTEGA-MORA, L. M. Epidemiology and control of neosporosis and Neospora caninum. Clinical Microbiology Reviews, Washington, v. 20, n. 2, p. 323-367, 2007.

EIRAS, C.; ARNAIZ, I.; ÁLVAREZ-GARCÍA, G.; ORTEGA-MORA, L. M.; SANJUÁNL, M. L.; YUS, E.; DIÉGUEZ, F. J. Neospora caninum seroprevalence in dairy and beef cattle from the northwest region of Spain, Galicia. Preventive Veterinary Medicine, Colorado, v. 98, n. 2, p. 128-132, 2011.

FERNÁNDEZ, J. G. F.; GARCÍA, F. Diagnóstico serológico de neosporosis bovina en fincas de la región de Tucacas, estado Falcón, Venezuela. Zootecnia Tropical, Maracay, v. 31, n. 4, p. 291-298, 2014.

GHAREKHANI, J. Seroprevalence of Neospora caninum and Toxoplasma gondii infections in aborted cattle in Hamedan, Iran. Journal of Advanced Veterinary and Animal Research, Bangladesh, v. 1, n. 2, p. 32-35, 2014.

GHAREKHANI, J.; TAVOOSIDANA, G.; AKBAREIN, H. Serological study of Neospora caninum infection in dogs and cattle from west of Iran. Comparative Clinical Pathology, Londres, v. 23, n. 5, p. 1203-1207, 2014.

GONDIM, L. F.; MCALLISTER, M. M.; PITT, W. C.; ZEMLICKA, D. E. Coyotes (Canis latrans) are definitive hosts of Neospora caninum. International Journal for Parasitology, Oxford, v. 34, n. 2, p. 159-161, 2004.

HASEGAWA, M. Y.; SARTOR, I. F.; CANAVESSI, Á. M. O.; PINCKNEY, R. D. Ocorrência de anticorpos antiNeospora caninum em bovinos de corte e em cães rurais da região de Avaré, Estado de São Paulo, Brasil. Semina: Ciências Agrárias, Londrina, v. 25, n. 1, p. 45-50, 2004.

INSTITUTO BRASILEIRO DE GEOGRAFIA E ESTATÍSTICA - IBGE. Cidades@: Informações estatísticas, Brasília: Pecuária, 2012. Disponível em: $\quad<$ http://cidades.ibge.gov.br/xtras/uf.php?lang $=\&$ coduf $=42 \&$ search $=$ santa-catarina $>$. Acesso em: 22 abril 2014.

KING, J. S.; ŠLAPETA, J.; JENKINS, D. J.; ALQASSAB, S. E.; ELLIS, J. T.; WINDSOR, P. A. Australian dingoes are definitive hosts of Neospora caninum. International Journal for Parasitology, Oxford, v. 40, n. 8, p. 945-950, 2010.

MARQUES, F. A. C.; HEADLEY, A. S.; FIGUEREDOPEREIRA, V.; TARODA, A.; BARROS, L. D.; CUNHA, I. A. L.; MUNHOZ, K.; BUGNI, F. M.; ZULPO, D. L.; IGARASHI, M.; VIDOTTO, O.; GUIMARÃES JUNIOR, J. S.; GARCIA, J. L. Neospora caninum: evaluation of vertical transmission in slaughtered beef cows (Bos indicus). Parasitology Research, Berlin, v. 108, n. 4, p. 1015-1019, 2011.

MCALLISTER, M. M.; DUBEY, J. P.; LINDSAY, D. S.; JOLLEY, W. R.; WILLS, R. A.; MCGUIRE, A. M. Rapid communication: dogs are definitive hosts of Neospora caninum. International Journal for Parasitology, Oxford, v. 28, n. 9, p. 1473-1479, 1998.

MINERVINO, A. H.; RAGOZO, A. M.; MONTEIRO, R. M.; ORTOLANI, E. L.; GENNARI, S. M. Prevalence of Neospora caninum antibodies in cattle from Santarém, Pará, Brazil. Research in Veterinary Science, Oxford, v. 84, n. 2, p. 254-256, 2008.

MORÉ, G.; BACIGALUPE, D.; BASSO, W.; RAMBEAUD, M.; VENTURINI, M. C.; VENTURINI, L. Serologic profiles for Sarcocystis sp. and Neospora caninum and productive performance in naturally infected beef calves. Parasitology Research, Berlin, v. 106, n. 3, p. 689-693, 2010.

MOURA, A. B.; GÜTHS, M. F.; FARIAS, J. A.; SOUZA, A. P.; SARTOR, A. A.; QUADROS, R. M. Neospora caninum seroprevalence and risk factors for ewes from Santa Catarina Plateau, Brazil. Semina: Ciências Agrárias, Londrina, v. 35, n. 5, p. 2591-2600, 2014.

MOURA, A. B.; OSAKI, S. C.; ZULPO, D. L.; GARCIA, J. L.; TEIXEIRA, E. B. Occurrence of anti-Neospora caninum antibodies in beef cattle of microrregion of Guarapuava, Paraná state, Brazil. Arquivos do Instituto Biológico, São Paulo, v. 79, n. 3, p. 419-422, 2012 a.

MOURA, A. B.; SILVA, M. O.; FARIAS, J. A.; VIEIRANETO, A.; SOUZA, A. P.; SARTOR, A. A.; FONTEQUE, J. H.; BUNN, S. Neospora spp. antibodies in horses from two geographical regions of the state of Santa Catarina, Brazil. Revista Brasileira de Parasitologia Veterinária, São Carlos, v. 22, n. 4, p. 597-601, 2013.

MOURA, A. B.; SOUZA, A. P.; SARTOR, A. A.; BELlATO, V.; PISETTA, G. M.; TEIXEIRA, E. B.; HEUSSER JUNIOR, A. Neospora caninum antibodies and risk factors in dogs from Lages and Balneário Camboriú, SC. Arquivo Brasileiro de Medicina Veterinária e Zootecnia, Belo Horizonte, v. 63, n. 1, p. 262-265, 2011.

MOURA, A. B.; SOUZA, A. P.; SARTOR, A. A.; BELLATO, V.; TEIXEIRA, E. B. Neospora caninum antibodies in dairy cattle of Lages Municipality, Santa Catarina State, Brazil. Archivos de Medicina Veterinaria, Valdivia, v. 44, n. 2, p. 117-122, 2012 b. 
NASCIMENTO, E. E.; SAMMI, A. S.; SANTOS, J. R.; NINO, B. D. S. L.; BOGADO, A. L. G.; TARODA, A.; VIDOTTO, O.; GARCIA, J. L. Anti-Neospora caninum antibody detection and vertical transmission rate in pregnant zebu beef cows (Bos indicus): Neospora caninum in pregnant beef cows (Bos indicus). Comparative Immunology, Microbiology and Infectious Diseases, New York, v. 37, n. 4, p. 267-270, 2014.

NASIR, A.; LANYON, S. R.; SCHARES, G.; ANDERSON, M. L.; REICHEL, M. P. Sero-prevalence of Neospora caninum and Besnoitia besnoiti in South Australian beef and dairy cattle. Veterinary Parasitology, Amsterdam, v. 186, n. 3, p. 480-485, 2012.

ORGANIZACION PANAMERICANA DE LA SALUD - OPS. Bioestatisica: procedimentos para estudios de prevalencia por muestreo. Buenos Aires: Organizacion Panamericana de la Salud, 1979. n. 18.

PAZ, G. F.; LEITE, R. C.; ROCHA, M. A. Association between seropositivity for Neospora caninum and pregnancy rate in bovine receipts submitted to embryo transfer technology. Arquivo Brasileiro de Medicina Veterinária e Zootecnia, Belo Horizonte, v. 59, n. 5, p. 1323-1325, 2007.

PORTOCARRERO, C.; PINEDO, R.; FALCÓN, N.; CHÁVEZ, A. Factores de riesgo asociados a la seroprevalencia de Neospora caninum en bovinos naturalmente infectados en la ceja de selva de Oxapampa, Perú. Revista de Investigaciones Veterinarias del Perú, Lima, v. 26, n. 1, p. 119-126, 2015.

REICHEL, M. P.; AYANEGUI-ALCÉRRECA, M. A.; GONDIM, L. F.; ELLIS, J. T. What is the global economic impact of Neospora caninum in cattle-the billion dollar question. International Journal for Parasitology, Oxford, v. 43, n. 2, p. 133-142, 2013.

SANTOLARIA, P.; ALMERÍA, S.; MARTÍNEZBELLO, D.; NOGAREDA, C.; MEZO, M.; GONZALEZWARLETA, M.; CASTRO-HERMIDA, J. A.; PABÓN, M.; YÁNIZ, J. L.; LÓPEZ-GATIUS, F. Different humoral mechanisms against Neospora caninum infection in purebreed and crossbreed beef/dairy cattle pregnancies. Veterinary Parasitology, Amsterdam, v. 178, n. 1, p. 7076, 2011.
SARTOR, I. F.; HASEGAWA, M. Y.; CANAVESSI, A. M. O.; PINCKNEY, R. D. Ocorrência de anticorpos de Neospora caninum em vacas leiteiras avaliados pelos métodos ELISA e RIFI no município de Avaré, SP. Semina: Ciências Agrárias, Londrina, v. 24, n. 1, p. 3-10, 2003.

SILVA, C. L.; FREITAS, J. A.; GARCIA, J. L.; ARAÚJO, C. V.; ZULPO, D. L.; LEME CUNHA, I. A. Serological survey of Neospora caninum in dairy herds from Parauapebas, State of Pará. Semina: Ciências Agrárias, Londrina, v. 36, n. 1, p. 231-238, 2015.

TOPAZIO, J. P.; WEBER, A.; CAMILLO, G.; VOGEL, F. F.; MACHADO, G.; RIBEIRO, A.; MOURA, A. B.; LOPES, S. L.; TONIN, A. A.; SOLDÁ, N. M.; BRAÜNIG, P.; SILVA, A. S. Seroprevalence and risk factors for Neospora caninum in goats in Santa Catarina state, Brazil. Revista Brasileira de Parasitologia Veterinária, São Carlos, v. 23, n. 3, p. 360-366, 2014.

VANLEEUWEN, J. A.; FORSYTHE, L.; TIWARI, A.; CHARTIER, R. Seroprevalences of antibodies against bovine leukemia virus, bovine viral diarrhea virus, Mycobacterium avium subspecies paratuberculosis, and Neospora caninum in beef and dairy cattle in Manitoba. The Canadian Veterinary Journal, Ottawa, v. 47, n. 8, p. 783-786, 2006.

VARASCHIN, M. S.; HIRSCH, C.; WOUTERS, F.; NAKAGAKI, K. Y.; GUIMARÃES, A. M.; SANTOS, D. S.; BEZERRA, P. S.; COSTA, R. C.; PECONICK, A. P.; LANGOHR, I. M. Congenital neosporosis in goats from the state of Minas Gerais, Brazil. The Korean Journal of Parasitology, Seoul, v. 50, n. 1, p. 63-67, 2012.

VIANNA, L. C.; SARTOR, I. F.; PITUCO, E. M.; OKUDA, L. H.; CAMARGO, C. N.; KRONKA, S. N. Incidence and transplacental transmission of Neospora caninum in primiparous females from Bos indicus slaughtered in Presidente Prudente, São Paulo, Brazil. Semina: Ciências Agrárias, Londrina, v. 29, n. 2, p. $387-$ 392, 2008. 
